\section{Status of waterbirds at Hathnikund Barrage wetland, Yamunanagar District, Haryana, India}

\author{
Prakash C. Tak ${ }^{1}$, Jagdish P. Sati ${ }^{2}$ \& \\ Anjum N. Rizvi ${ }^{3}$ \\ 1,2,3 Zoological Survey of India, Northern Regional Centre, \\ 218-Kaulagarh Road, Dehra Dun, Uttarakhand 248195, India \\ Email: ${ }^{1}$ pctakzsi@gmail.com; ${ }^{2}$ jpsatizsi@yahoo.co.in; \\ ${ }^{3}$ anrizvi@gmail.com (corresponding author)
}

The present study on status of waterbirds of Hathnikund Barrage wetland was undertaken while conducting 'General Faunistic Surveys' of Kalesar National Park and Wildlife Sanctuary under primary objectives of the Zoological Survey of India, Dehra Dun. This wetland is a small area of about $1 \mathrm{~km}^{2}$ in Yamunanagar District of Haryana. The barrage was constructed from October 1996 to June 1999 and came into being in the year 1999 under the West Jamuna Canal Project to substitute Tajewala water-head (constructed way back in 1873 and has now become non-functional) primarily for irrigation and power generation for Haryana and Uttar Pradesh. It is adjacent to the national park and is practically inseparable. Geographically, the wetland is located at $30^{\circ} 19.290^{\prime} \mathrm{N} \& 7^{\circ} 02.579^{\prime} \mathrm{E}$ at an elevation of $c .310 \mathrm{~m}$. Fishing activities are not allowed in the barrage.

Kalsi (1998) was, perhaps, the first to provide a list of 161 species of birds from the Kalesar Sanctuary, while Sharma (2006) made available an updated and an unannotated checklist of 304 species on the internet. To this

Date of publication (online): 26 April 2010

Date of publication (print): 26 April 2010

ISSN 0974-7907 (online) | 0974-7893 (print)

Editor: Rajah Jayapal

Manuscript details:

Ms \# 02200

Received 08 May 2009

Final received 24 December 2009

Finally accepted 03 March 2010

Citation: Tak, P.C., J.P. Sati \& A.N. Rizvi (2010). Status of waterbirds at Hathnikund Barrage wetland, Yamunanagar District, Haryana, India. Journal of Threatened Taxa 2(4): 841-844.

Copyright: (c) Prakash C. Tak, Jagdish P. Sati \& Anjum N. Rizvi 2010 Creative Commons Attribution 3.0 Unported License. JoTT allows unrestricted use of this article in any medium for non-profit purposes, reproduction and distribution by providing adequate credit to the authors and the source of publication.

Acknowledgements: We are grateful to Dr. Ramakrishna, Director Zoological Survey of India, Kolkata for encouragement throughout. We are also thankful to Shri P. T. Bhutia, Scientist- ' $F$ ' and Officer-in-Charge, Zoological Survey of India, Dehra Dun for various facilities.

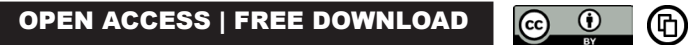

checklist, Bahuguna et al. (2008) added five species of waterbirds. The present communication adds another five waterbird species. However, these studies did not deal with the status of waterbirds of Hathnikund, though a few studies on the status and diversity of waterbirds of two other man-made wetlands (Asan and Bheemgoda barrage wetlands) from the nearby areas are available (Tak et al. 1998; Kumar \& Bhatt 2000; Tak \& Sati 2003).

\section{Material and Methods}

Observations on the waterbird diversity and relative abundance at Hathnikund were carried out for two successive winters between October and March during 2007-08 and 2008-09. Regular surveys at monthly intervals were undertaken. In all, 12 visits were made to the wetlands. Each time the absolute counts were made by two to three observers to minimize errors. Relative abundance was assessed in terms of the following four categories: i) very common (observed in $75-100 \%$ of visits); ii) common (50-74\%); iii) uncommon (25-49\%) and iv) less common $(<25 \%)$. The nomenclature and systematic sequence of birds as given by Manakadan \& Pittie (2001) was followed.

\section{Results}

The observations revealed that this wetland provides habitat for 31 waterbirds species belonging to 22 genera and 10 families, including the five waterbirds species (Barheaded Goose Anser indicus, Gadwall Anas strepera, Mallard Anas platyrhynchos, Red-crested Pochard Rhodonessa rufina, and Common Pochard Aythya ferina), which have been added for the first time to the existing checklist on avifauna of the area.

Of these, 14 species are widespread resident $(R)$, one widespread resident whose population augmented by winter visitors (RW), 11 widespread winter visitors $(W)$, and the remaining five species are sparse local winter visitors (w) (Table 1).

The family-wise proportion of species richness of waterbirds of Hathnikund Barrage varied from 35.4 to 3.2 $\%$ as follows: family Anatidae with 11 species (35.4\%), followed by Ardeidae 6 (19.3\%); Scolopacidae three (9.6\%), Phalacrocoracidae, Rallidae, Charadriidae, and Laridae with two species each (6.4\% each), and Podicipedidae Ciconiidae, and Recurvirostridae by a single species each (3.2\% each) (Fig. 1).

While the proportion of avian families as represented by population abundance (average population: 344.7 ; range: 47-919 individuals) was: Anatidae with $83.9 \%$, followed by Phalacrocoracidae (10.2\%), Ardeidae (3.4\%), Podicipedidae $(0.6 \%)$, Charadriidae $(0.51 \%)$, Rallidae and Recurvirostridae (0.34\% each), Laridae $(0.19 \%)$, Scolopacidae (0.14\%), and Ciconiidae (0.1\%) (Fig. 2). 
Table 1. Status of waterbirds at Hathnikund Barrage wetland, Yamunanagar District, Haryana, India.

\begin{tabular}{|c|c|c|c|c|c|c|}
\hline & \multicolumn{2}{|l|}{ Sytematic list } & 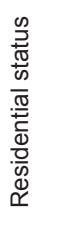 & 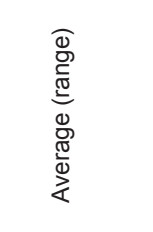 & 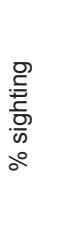 & 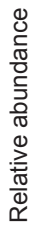 \\
\hline & \multicolumn{2}{|l|}{ Podicipedidae } & & & & \\
\hline \multirow[t]{2}{*}{1} & Little Grebe (5) & Tachybaptus ruficollis (Pallas, 1764) & $\mathrm{R}$ & $2.3(0-6)$ & 50 & C \\
\hline & \multicolumn{2}{|l|}{ Phalacrocoracidae } & & & & \\
\hline 2 & Little Cormorant (28) & Phalacrocorax niger (Vieillot, 1817) & $\mathrm{R}$ & $15(0-50)$ & 83.3 & VC \\
\hline \multirow[t]{2}{*}{3} & Great Cormorant (26) & Phalacrocorax carbo (Linnaeus, 1758) & RW & $20.5(0-60)$ & 91.6 & VC \\
\hline & \multicolumn{2}{|l|}{ Ardeidae } & & & & \\
\hline 4 & Little Egret (49) & Egretta garzetta (Linnaeus, 1766) & $\mathrm{R}$ & $9.7(0-30)$ & 75 & VC \\
\hline 5 & Grey Heron (35-36) & Ardea cinerea Linnaeus, 1758 & W & $0.2(0-2)$ & 16.6 & LC \\
\hline 6 & Large Egret (45-46) & Casmerodius albus (Linnaeus, 1758) & $\mathrm{R}$ & $0.5(0-2)$ & 50 & C \\
\hline 7 & Median Egret $(47,48)$ & Mesophoyx intermedia (Wagler, 1829) & $\mathrm{R}$ & $0.08(0-1)$ & 8.3 & LC \\
\hline 8 & Cattle Egret (44) & Bubulcus ibis (Linnaeus, 1758) & $\mathrm{R}$ & $1.7(0-7)$ & 41.6 & UC \\
\hline \multirow[t]{2}{*}{9} & Indian Pond-Heron (42-42a) & Ardeola grayii (Sykes, 1832) & $\mathrm{R}$ & $0.2(0-1)$ & 25 & UC \\
\hline & \multicolumn{2}{|l|}{ Ciconiidae } & & & & \\
\hline \multirow[t]{2}{*}{10} & Black Stork (65) & Ciconia nigra (Linnaeus, 1758) & w & $0.4(0-5)$ & 8.3 & LC \\
\hline & \multicolumn{2}{|l|}{ Anatidae } & & & & \\
\hline 11 & *Bar-headed Goose (82) & Anser indicus (Latham, 1790) & w & $0.3(0-4)$ & 8.3 & LC \\
\hline 12 & Brahminy Shelduck (90) & Tadorna ferruginea (Pallas, 1764) & W & $160(21-350)$ & 91.6 & VC \\
\hline 13 & *Gadwall (101) & Anas strepera Linnaeus, 1758 & W & $47(0-120)$ & 66.6 & C \\
\hline 14 & Eurasian Wigeon (103) & Anas penelope Linnaeus, 1758 & W & $8.3(0-100)$ & 8.3 & LC \\
\hline 15 & *Mallard (100) & Anas platyrhynchos Linnaeus, 1758 & W & $3.5(0-36)$ & 25 & UC \\
\hline 16 & Spot-billed Duck (97-99) & Anas poecilorhyncha J.R. Forester, 1781 & $\mathrm{R}$ & $11.3(0-20)$ & 75 & VC \\
\hline 17 & Northern Shoveller (105) & Anas clypeata Linnaeus, 1758 & W & $0.1(0-2)$ & 8.3 & LC \\
\hline 18 & Northern Pintail (93) & Anas acuta Linnaeus, 1758 & W & $17.5(0-150)$ & 16.6 & LC \\
\hline 19 & *Red-crested Pochard (107) & Rhodonessa rufina (Pallas, 1773) & w & $15.2(0-60)$ & 58.3 & C \\
\hline 20 & ${ }^{*}$ Common Pochard (108) & Aythya ferina (Linnaeus, 1758) & W & $21.1(0-90)$ & 50 & C \\
\hline \multirow[t]{2}{*}{21} & Tufted Pochard (111) & Aythya fuligula (Linnaeus, 1758) & W & $3.3(0-40)$ & 8.3 & LC \\
\hline & \multicolumn{2}{|l|}{ Rallidae } & & & & \\
\hline 22 & Common Moorhen (347-347a) & Gallinula chloropus (Linnaeus, 1758) & $\mathrm{R}$ & $0.3(0-2)$ & 16.6 & LC \\
\hline
\end{tabular}




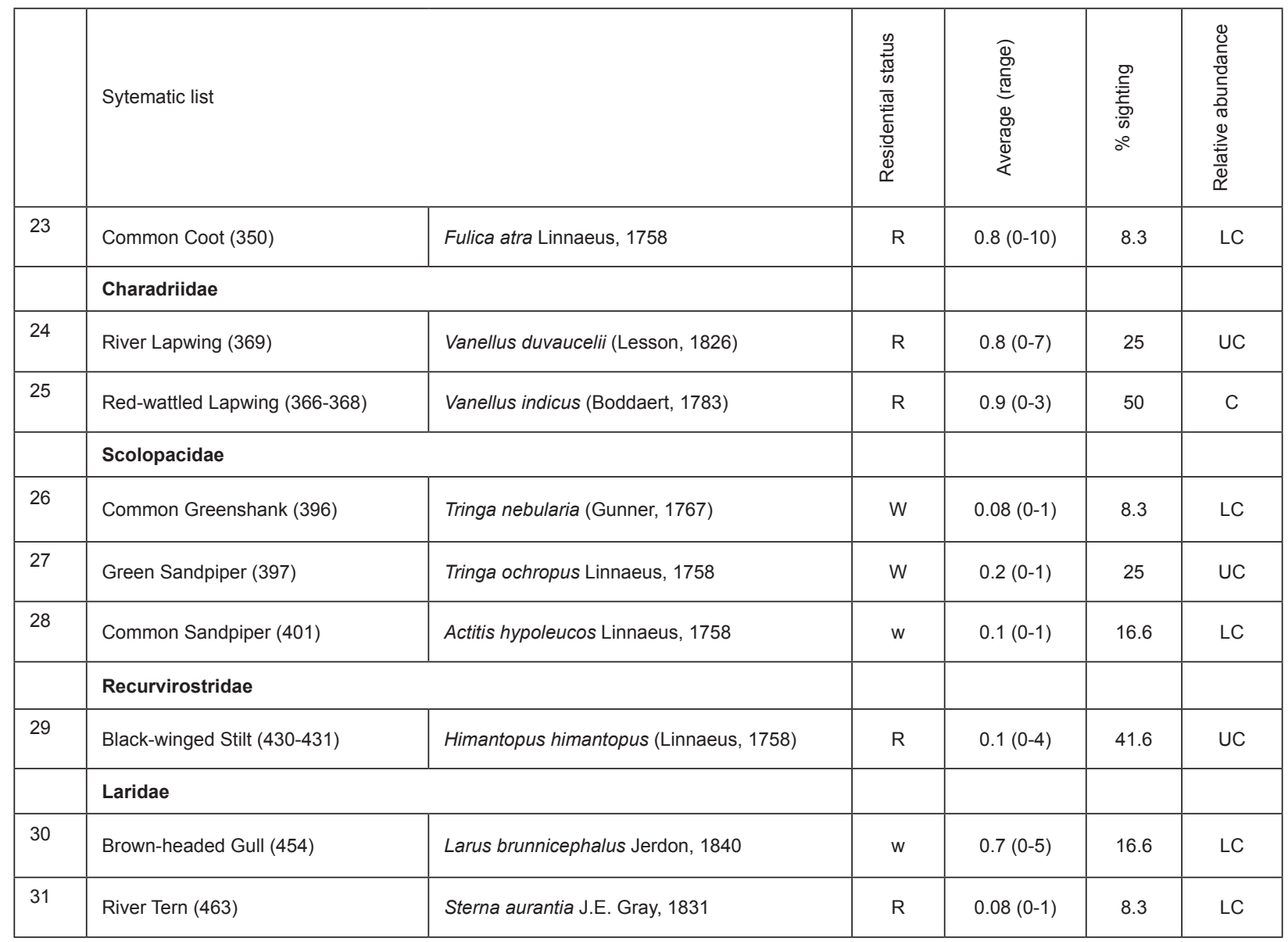

* - species added for the first time to the existing avifaunal checklist of Kalesar area; VC - very common; C - common; UC - uncommon; LC - less common; R - widespread resident; RW - widespread resident as well as widespread winter migrant; $\mathrm{W}$ - widespread winter migrant; $\mathrm{w}$ - sparse local winter migrant. Numbers within brackets after the common names are the numbers given to species in Ripley's (1982) Synopsis, which was also followed in Ali \& Ripley's Handbook.

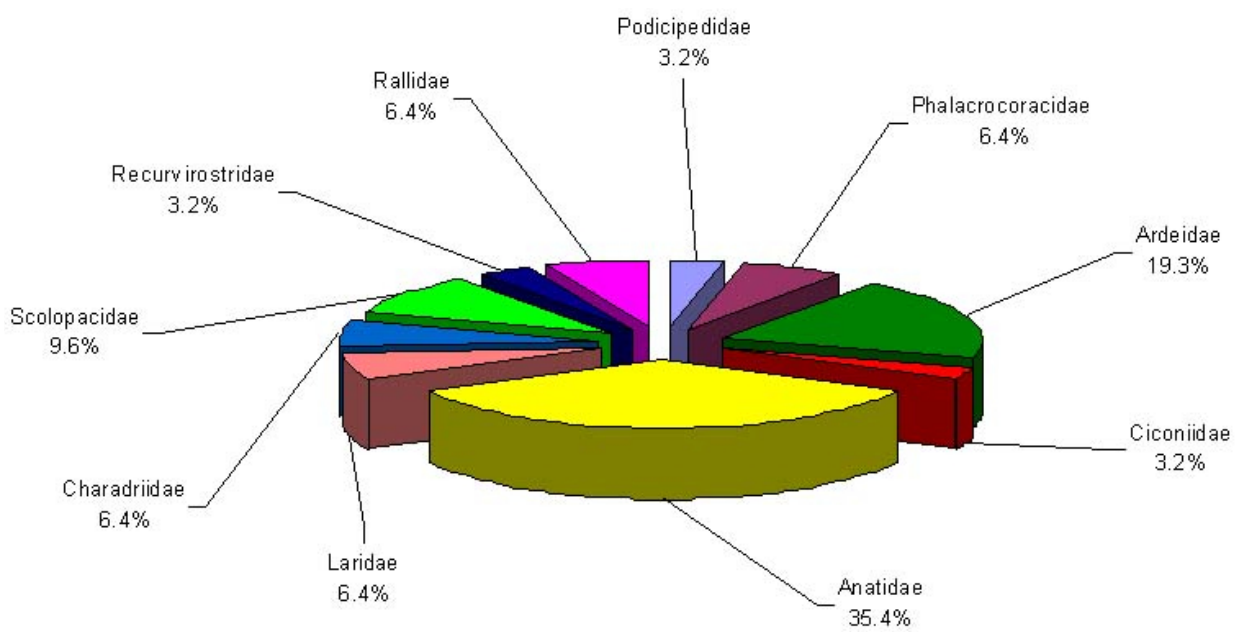

Figure 1. Proportion of avian families as represented by species richness of waterbirds of Hathnikund Barrage 


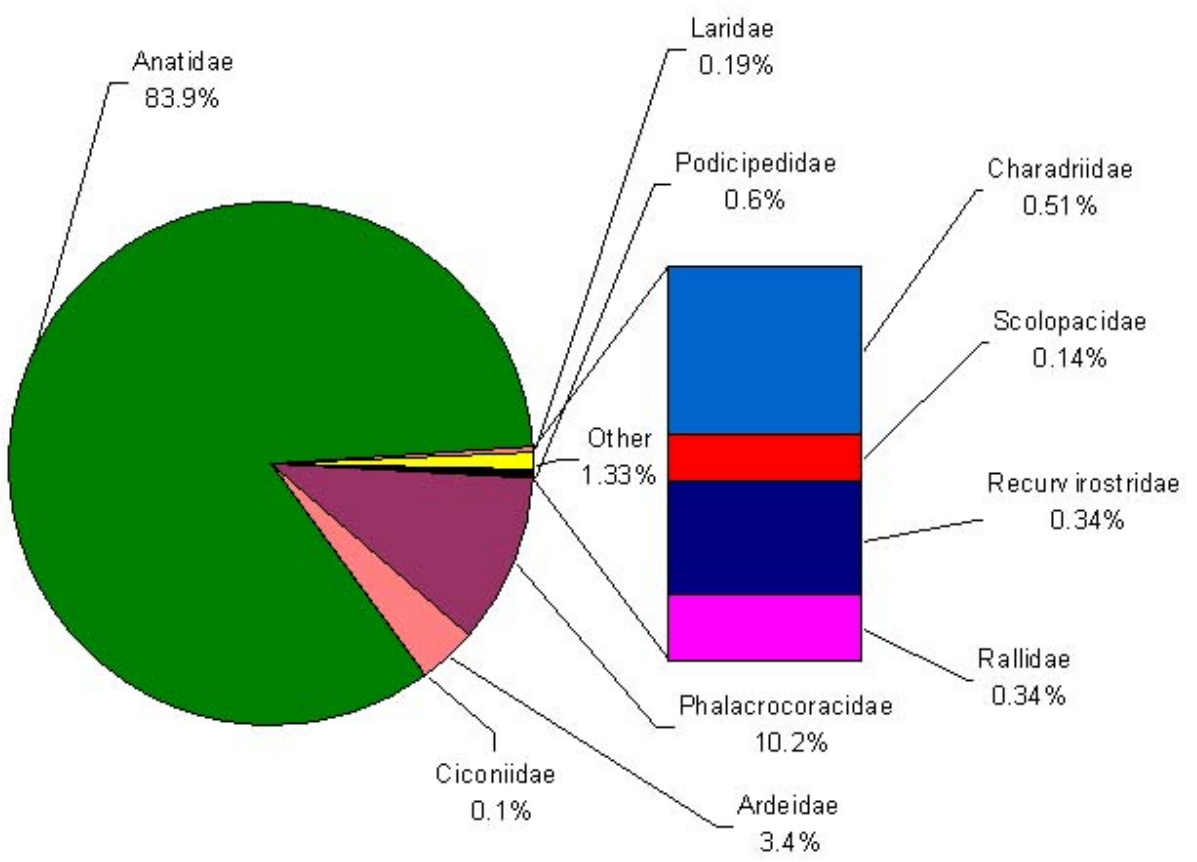

Figure 2. Proportion of avian families as represented by population abundance of waterbirds of Hathnikund Barrage

The species-wise average population and range have also been provided in Table 1.

The observations on the relative abundance of 31 waterbird species revealed that five species were very common (Great Cormorant \& Brahminy Shelduck with 91.6\%; Little Cormorant 83.3\%; Little Egret \& Spot-billed Duck $75 \%$ ) and six species were common (Gadwall with 66.6\%, Red-crested Pochard 58\%, Little Grebe, Large Egret, Common Pochard \& Red-wattled Lapwing 50\%), while another six species were uncommon and the remaining 14 species were less common

\section{Remarks}

The occurrence of an average population of c. 350 individuals of 31 waterbird species during the study period is, perhaps, an indication of the fact that in near future the Hathnikund barrage wetlands may not only become a favourable habitat for waterbirds but may also develop into an ideal place for birdwatchers, naturalists, tourists, and researchers, since the waterbirds are of great importance for their esthetic, sporting, and economic values.

\section{REFERENCES}

Bahuguna, A., J.P. Sati \& P.C. Tak (2008). Sighting of Black Stork (Ciconia nigra) in Kalesar National Park, Yamunanagar district, Haryana, India. Newsletter for Birdwatchers 48(4): 49-50.

Kalsi, R.S. (1998). Birds of Kalesar Wildlife Sanctuary, Haryana, India. Forktail 13: 29-32.

Kumar, A. \& D. Bhatt (2000). Status of migratory avifauna of subtropical wetland in Ganga Valley, Haridwar, India. Annals of Forestry 8(1): 17-24.

Manakadan, R. \& A. Pittie (2001). Standardised common and scientific names of the birds of the Indian subcontinent. Buceros 6(1): i-ix+1-37.

Sharma, S.C. (2006). Birds of Kalesar National Park (Haryana) - An Un-annotated Checklist (with foreword by Bill Harvey) downloaded from internet in 2007. http://www.haryanaonline.com/fauna/haryana_birds.htm. Accessed on 06 March 2007.

Tak, P.C. \& J.P. Sati (2003). AVES. In Fauna of Asan Wetland, Wetland Ecosystems Series. Zoological Survey of India 5: 31-38.

Tak, P.C., J.P. Sati \& A. Kumar (1998). Waterfowl potential of Asan Reservoir (Dehra Dun Valley, India). Zoologie 5(2): 111-132. 